\title{
Assessment of Ground Water Resources for Irrigation in Aurngabad District of South Bihar, India
}

\author{
Ravish Chandra*, Shilpi Kumari, S.K. Jain and A.K. Singh
}

Dr. Rajendra Prasad Central Agricultural University, Pusa, Samastipur-848125, India

*Corresponding author

\section{Keywords \\ Canal water, Ganga Alluvial Plain, Ground water, GEC 97, Water table fluctuation \\ technique, Groundwater draft \\ Article Info \\ Accepted: \\ 12 March 2018 \\ Available Online: \\ 10 April 2018}

\section{A B S T R A C T}

The Indo-Gangetic plains comprise of large floodplains of the Indus and GangesBrahmaputra river systems. They are home to approximately 1 billion people and encompass northern and eastern India, much of Bangladesh, parts of southern Nepal and the most populous parts of Pakistan. Ground Water remains the lifeline of socioeconomic development in the Ganga Alluvial Plain (GAP) since the down of civilization in the Indian subcontinent. Assessment of groundwater resources yields knowledge necessary for their informed management and governance. Keeping the importance of the above points a study was conducted for assessment of ground water resources in Nalanda district of south Bihar. The aim for the assessment of groundwater in Aurangabad district was to compute a complete evaluation of groundwater resources and produce information that can be incorporated for future requirement. The study was undertaken based on the recommendation of groundwater estimation committee, 1997 (GEC-97). Methodology used the estimation of annual groundwater recharge from rainfall and other sources, including irrigation, water bodies and artificial recharge, determination of present status of groundwater utilization and categorization of assessment units based on the level of groundwater utilization and long-term water level trend. Water level fluctuation techniques and empirical norms were used for recharge estimation. The data collected for investigation were water table fluctuation data, rainfall data cropping pattern, number of groundwater structures, hydrogeology of area, specific yield, groundwater draft, pond area etc. The total annual ground water recharge is 89882 ha-m for Aurangabad district. The existing ground water draft for irrigation is 15191 ha-m for Aurnagabad district. The ground water draft for all uses is 18703 ha-m for Aurangabad district. The net annual replenishable ground water resource is worked out to be 73054 ha-m for Aurangabad district. The net annual ground water available for future irrigation development is 56562 ha-m for Aurangabad district. The stage of ground water development is $23.1 \%$ for Aurangabad district. According to definitions used by CGWB Aurangabad district falls in safe category. The study recommended that there is a good scope for future groundwater development and conjunctive use of canal irrigation and ground water needs to be promoted. 


\section{Introduction}

Groundwater has an important role in the environment. It replenishes streams, rivers, and wetlands and helps to support wildlife habitat; it is used as primary source of drinking water and also in agricultural and industrial activities. Rainwater is the main source of water for agriculture but its current use efficiency for crop production is low (30$45 \%$ ). Groundwater, which is $38.5 \%$ of the available water sources of the country, plays a major role in irrigation, rural and urban drinking water supply and industrial development. Groundwater meets nearly 55\% irrigation, $85 \%$ of rural and $50 \%$ of urban and industrial needs (Government of India, 2007).

Around the world, groundwater resources are under increasing pressure caused by the intensification of human activities and other factors such as climate changes. The prime cause of over-exploitation of groundwater is the rising demand from agriculture and rapid growth in urbanization and industrialization. In many groundwater irrigated areas, the decisions on cropping pattern and cropping intensity are being taken largely independent of the groundwater availability. Thus water intensive crops have tended to be grown in the face of scarcity of water. Over-exploitation of groundwater leads to: reduction in water yield in the wells, increase in pumping depth and cost of pumping, contamination of groundwater due to geo-genic factors, resulting in increasing levels of fluoride, arsenic, iron and most importantly, in the failure of wells causing heavy economic losses to the farmers.

Groundwater development in the country has expanded extensively. Over-exploitation of the resource in most parts of the country has led to a rapid decline in the groundwater table. This has threatened not only the food security and environment, but also the sustainable development. Further depletion of groundwater resource has been affecting the small and marginal farmers the most, threatening their livelihood in many cases.

Access to groundwater can be a major engine for food security, poverty alleviation and economic development in the rural areas. The effective management and utilization of groundwater not only as a source of water for agriculture and other consumptive purposes, but also as a supplementary source of surface water flows, wetlands and wildlife habitats calls for an increased attention to the two major and interdependent source of concern: depletion and pollution. The ground water management is the major challenge facing the water resources because once it modified and contaminated, ground water can be very costly and difficult to restore. Therefore, a focus on the development activities must be balanced by management mechanisms, enabling policy and institutional mechanisms to achieve a sustainable utilization of ground water resources. Ground water management in the over exploited regions needs to be taken up by incorporating artificial recharge to ground water from in-situ and ex-situ rain water harvesting through integrated watershed intervention. This has led to emphasis on ground water assessment for planned and optimal development of water resources.

The Bihar state forms a part of mid-Ganga plain. The river Ganges flows in the state in west-east direction. The area falling in the north of the Ganga River is a monotonous flat land having regional slope towards south with altitude ranging from $887 \mathrm{~m}$ above msl to 34 $\mathrm{m}$ above msl. The area in the south of the Ganga River has the regional slope towards north. The southern border of the state is marked with presence of topographic highs made up of extensions the Chotanagpur plateau covering vast stretch in the Jharkhand state. The highest point observed in this part is 
$637 \mathrm{~m}$ above msl in Kaimur district. About $33 \%$ of the geographical area of the state in the south of the Ganga River is covered by alluvial deposits often referred to as marginal alluvial plain. Ground water remains the life line of socio-economic development in the Ganga alluvial plain (GAP) since the dawn of civilization in the Indian subcontinent. The quaternary sequence forming top layer of the thick unconsolidated sediments of the GAP, holds nearly $30 \%$ of the total annual replenishable ground water resources of India (Govt. of India, 2006). Increasing groundwater extraction from GAP has resulted in surfacing of aquifer stress symptoms like lowering of ground water level and ground water quality deterioration (World Banks, 1998).

A recent assessment in the three states of North and East India, viz. U.P., Bihar and West Bengal covering nearly $80 \%$ of GAP, identified 37 community development blocks (Ground water resource assessment unit) under over exploited category. Ground water extraction has exceeded the annual replenishable resource (Govt. of India, 2006). A planned approach is therefore essential for sustainable development of this precious natural resource as dependence on ground water is likely to increase in future. For this the first task would be to make a realistic assessment of ground water resources and the plan their use in such a way that full crop water requirement are met and there is neither water logging nor excessive water lowering of ground water table. It is necessary to maintain the ground water reservoir in a state of dynamic equilibrium over a period of time and the water level fluctuations have to be kept within a particular range over the monsoon and non-monsoon seasons. Keeping the above things in mind the present study of the ground water assessment of Aurangabad district which falls in agro-climatic zone- IIIA, was taken up.

\section{Study area}

This district is the extreme south west part of ancient Magadh division. The command area of the system is located between $24^{0} .45^{\prime}$ North and $84^{\circ} .22^{\prime}$ East with a height of $84 \mathrm{~m}$ from mean sea level. This district encompasses an geographical area of 3305 square kilometres. Aurangabad district has been carved from Gaya district. As per the boundary of the district is concerned to the east of the district lies Gaya, to the west Rohtas, to the south Palamu of the Jharkhand province and to the north is Arwal.

The district comprises of two administrative subdivisions namely as Aurangabad and Daudnagar. The whole district is divided into 11 blocks, two municipalities, 203 panchayats, 1884 villages, 2838 wards.

\section{Geomorphology}

Aurangabad district is a part of the IndoGangetic alluvium, one of the three main physiographic divisions of India, which separates Extra-Peninsular regions on the north from the peninsular region on the south. The level plain is known to be the outcome of a granular filling of a great depression with alluvial sediments since Middle Pleistocene times. The area under study is underlain by alluvial sediments of quaternary age. Aurangabad district comes under the porous formations (the Quaternary alluvial deposits) accept the three blocks (Deo, Madanpur and Rafiganj), which come under the fissured formation with Quaternary alluvial, Precambrian granite gneiss rock formation. The thickness of the alluvial deposit ranges to a maximum of $700 \mathrm{~m}$.

\section{Soils}

Aurangabad district is situated in the south Bihar alluvial plains (zone 3B) of divided 
Bihar. Zone $3 \mathrm{~B}$ is the alluvial plains of river Ganga on its southern side. The land's slope is towards north east with gentle slope gradient and moderate to low gradient. There are no marshy lands in this zone.

The soil of Aurangabad district is highly suitable for the agriculture of paddy, wheat and sugar-cane. Betel leaves are grown at large scale in Aurangabad. In fact the irrigation-planning has made the land of the district most fertile and suitable for agriculture. But some of the physical problems of soil in this district also occur - low to very low permeability, clay pan formation.

\section{Climatic condition}

The climate of this district is generally a tropical monsoon type. During the summer days temperature rises up to 40 to $50^{\circ} \mathrm{c}$ whereas during winter temperature falls almost $8^{0} \mathrm{c}$. The hot weather begins from the middle of March when hot westerly winds begin to blow during the day. The months of April and May are extremely hot. Normally the monsoon sets in by the third week of June and continues with intermission till the end of September. The cold weather begins from the months of November and lasts till the beginning of March, January is the coldest month when the temperature comes down as low as $8^{\circ} \mathrm{C}$.

\section{Rainfall}

Average annual rainfall in the region is around $950.17 \mathrm{~mm}$. The agro-climatic conditions prevailing in the district favours the cultivation of different crops viz. paddy, wheat, lentils.

\section{Rivers}

Sone, Punpun, Auranga, Batane, Morhar, Adari, are the main rivers of Aurangabad district. Batane, Adari and Madar are the three big rivers of this district. Three fourth part of Aurangabad district is irrigated by river Sone.

\section{Irrigation facilities}

Almost part of Aurangabad district are irrigated by number of canals Eastern Sone High level canal (1403.00 m long), Eastern Link canal (4400.00 m long), Patna Main canal (3000 m long) and distributory canals are Mali distributory (325 m long), Kochasa distributory (300 m long), Amra distributory (180 m long) and Imamganj distributory (200 $\mathrm{m}$ long). The canal system is connected with natural drains and rivers to discharge surplus water of canal. The main and branch canals of the system are designed as ridge canals and run mostly in cutting or partial cutting. Besides canal system the other sources of irrigation are ground water, ponds, reservoirs etc.

\section{Cropping pattern}

Aurangabad district comes under south Bihar alluvial plains Zone $3 \mathrm{~B}$ of divided Bihar. In this zone followed by wheat is the most important crop, occupying 32\% \& 22\%, respectively of the gross area under irrigation.

The level of crop production technology is much higher as compared to any other zone. The cultivators of this zone have been very progressive. In upland, potato has been very important crop of this region. Two crops of potato in Ravi seasons are taken after kharif maize or early rice. In low lying paddy fields, Lathyrus, Gram, and Lentil are taken as paira crops.

\section{Irrigation structure}

There are 6203 dugwells, 8589 shallow tubewells and 96 deep tubewells in Aurangabad district. 


\section{Specific yield}

It is defined as the actual volume of water that can be extracted by the force of gravity from a unit volume of aquifer material is known as the specific yield. It is expressed as

$\mathrm{S}_{\mathrm{y}}=\frac{V_{d}}{v} \times 100$

Where,

$\mathrm{V}_{\mathrm{d}}=$ Volume of water that can be extracted by the force of gravity.

$\mathrm{V}=$ Total volume

The value of specific yield for Bhojpur, Buxar and Aurangabad districts has been taken as 0.10 .

\section{Ground water draft}

The amount of ground water extracted from the ground resources with the help of pumping unit is called ground water draft.

The gross ground water draft would include the ground water extraction from all existing ground water structures.

The ground water draft was calculated by the number of wells of different types multiplied by unit draft. The number of ground water structures is based on last minor irrigation census (2000-01). The table 2 shows the norms of GEC-1997 for ground water draft of Bihar state.

\section{Recharge from return flow from ground water irrigation}

Recharge from return flow from ground water irrigation is considered to be $30 \%$ of annual ground water draft during monsoon season as per the GEC-97 norms.

\section{Recharge due to seepage from canals}

Recharge due to seepage from canals was evaluated by using norms given in GEC-97. The following norms was adopted

For unlined canals in normal type of soil with some clay content along with the sand: 15-20 ham $/$ day $/ 10^{6}$ sq. m of wetted area.

For unlined canals in sandy soils: -25 to 30 ham $/$ day $/ 10^{6}$ sq. $m$ of wetted area.

For lined canals, the seepage losses may be taken as $20 \%$ of the above

\section{Recharge from ponds}

It is taken as $1.4 \mathrm{~mm} /$ day for the period in which the pond has water, based on the average area of water spread as per GEC-97 norms.

\section{Materials and Methods}

The present methodology used for resource assessment is known as ground water resource estimation methodology-1997 (GEC-97). Two approaches recommended are - Water level fluctuation method and Rain infiltration method.

\section{Ground water recharge}

\section{Monsoon recharge (water table fluctuation method)}

The recharge assessment during monsoon season is made as the sum total of the change in storage and gross draft.

The change in storage is computed by multiplying water level fluctuation between pre and post monsoon periods with the area of assessment and specific yield. Monsoon recharge can be expressed as 
$\mathrm{R}=\mathrm{S}+\mathrm{DG}=\mathrm{h} \times \mathrm{S}_{\mathrm{y}} \times \mathrm{A}+\mathrm{DG}(2)$

Where,

$\mathrm{R}=$ Recharge during monsoon, ha-m

$\mathrm{S}=$ Change in storage, $\mathrm{m}$

$\mathrm{DG}=$ Gross draft during monsoon season, ha$\mathrm{m}$

$\mathrm{h}=$ Rise in water table during monsoon season, $\mathrm{m}$

$S_{\mathrm{y}}=$ Specific yield and

$\mathrm{A}=$ Area of assessment. ha

The monsoon ground water recharge has two component - (a) rainfall recharge and (b) recharge from other sources.

The recharge calculated from equation (2) gives the available recharge from rainfall and other sources for the particular monsoon season. The recharge from rainfall is given by,

$\mathrm{R}_{\mathrm{rf}}=\mathrm{R}-\mathrm{R}_{\mathrm{gw}}-\mathrm{R}_{\mathrm{wc}}-\mathrm{R}_{\mathrm{t}}-\mathrm{R}_{\mathrm{c}}$

Hence,

$\mathrm{R}_{\mathrm{rf}}=\mathrm{h} \times \mathrm{S}_{\mathrm{y}} \times \mathrm{A}+\mathrm{DG}-\mathrm{R}_{\mathrm{gw}}-\mathrm{R}_{\mathrm{wc}}-\mathrm{R}_{\mathrm{t}}-\mathrm{R}_{\mathrm{c}}$ (3)

Where,

$\mathrm{R}_{\mathrm{rf}}=$ Recharge from rainfall, ha-m

$\mathrm{R}_{\mathrm{gw}}=$ Recharge from return flow from groundwater irrigation in the area, ha-m

$\mathrm{R}_{\mathrm{wc}}=$ Recharge from water conservation structures, ha-m

$\mathrm{R}_{\mathrm{t}}=$ Recharge from ponds, ha-m and

$\mathrm{R}_{\mathrm{c}}=$ Recharge from canal system, ha-m
The recharge from rainfall estimated as per equation (3) is for the particular monsoon season. The procedure for normalisation of this recharge for estimating recharge corresponding to the normal monsoon rainfall is given in the coming section.

\section{Estimation of normal recharge during monsoon season}

The rainfall recharge obtained by using equation (3) provides the recharge in any particular monsoon season for the associated monsoon season rainfall.

This estimate is to be normalised for the normal monsoon season rainfall which in turn is obtained as the average of the monsoon season rainfall for the recent 30 to 50 years. The rainfall recharge, $\left(\mathrm{R}_{\mathrm{rf}}\right)_{\mathrm{i}}$ for the $\mathrm{i}^{\text {th }}$ particular year is obtained as per the equation given below

$\left(\mathrm{R}_{\mathrm{rf}}\right)_{\mathrm{i}}=\mathrm{R}-\mathrm{R}_{\mathrm{gw}}-\mathrm{R}_{\mathrm{wc}}-\mathrm{R}_{\mathrm{t}}-\mathrm{R}_{\mathrm{c}}$

$\left(R_{\mathrm{rf}}\right)_{\mathrm{i}}=\mathrm{h} \times \mathrm{S}_{\mathrm{y}} \times \mathrm{A}+\mathrm{DG}-\mathrm{R}_{\mathrm{gw}}-\mathrm{R}_{\mathrm{wc}}-\mathrm{R}_{\mathrm{t}}-\mathrm{R}_{\mathrm{c}}$

Where,

$\left(\mathrm{R}_{\mathrm{rf}}\right)_{\mathrm{i}}=$ Rainfall recharge estimated for the $\mathrm{i}^{\text {th }}$ particular year, ha-m

$\mathrm{h}=$ Rise in water table during monsoon season for the $\mathrm{i}^{\text {th }}$ particular year, $\mathrm{m}$

$\mathrm{S}_{\mathrm{y}}=$ Specific yield,

$\mathrm{A}=$ Area of assessment, ha

$\mathrm{DG}=$ Gross ground water draft during monsoon season for the $\mathrm{i}^{\text {th }}$ particular year, ha$\mathrm{m}$

$\mathrm{R}_{\mathrm{gw}}=$ Recharge from groundwater irrigation in the monsoon season for the $\mathrm{i}^{\text {th }}$ particular year, ha-m 
$\mathrm{R}_{\mathrm{wc}}=$ Recharge from water conservation structures, ha-m

$\mathrm{R}_{\mathrm{t}}=$ Recharge from ponds, ha-m

$\mathrm{R}_{\mathrm{c}}=$ Recharge from canal system, ha-m

Those values of $\left(\mathrm{R}_{\mathrm{rf}}\right)_{\mathrm{i}}$ obtained above which are negative or nearly zero should be omitted, and only the data in which $\left(\mathrm{R}_{\mathrm{rf}}\right)_{\mathrm{i}}$ is greater than zero should be considered for further computations in the normalisation procedure. It is also likely that all the $\left(\mathrm{R}_{\mathrm{rf}}\right)_{\mathrm{i}}$ values as obtained above are consistently negative or nearly zero. In such a case, the water table fluctuation method should be dispensed with, and the normal rainfall recharge during the monsoon season should be estimated by the rainfall infiltration factor method based on rainfall infiltration factors.

The computational procedure to be followed in the method is as given below

Each pair of $\left(R_{r f}\right)_{i}$ and $r_{i}$ are used to obtain $\left[R_{r f}\right.$ (normal) $]_{i}$, as

$\left[\mathrm{R}_{\mathrm{rf}}(\text { normal })\right]_{\mathrm{i}}=\frac{\left(\mathrm{R}_{\mathrm{rf}}\right)_{\mathrm{i}} \times \mathrm{r}(\text { normal })}{\mathrm{r}_{\mathrm{a}}}$

Where,

$\mathrm{r}($ normal $)=$ Normal rainfall value of 30 years

(1980-2010) rainfall, $\mathrm{mm}$

$\mathrm{r}_{\mathrm{a}}=$ Annual rainfall, $\mathrm{mm}$

$\left(\mathrm{R}_{\mathrm{rf}}\right)_{\mathrm{i}}=$ Rainfall recharge estimated for the $\mathrm{i}^{\mathrm{th}}$ particular year, ha-m

The normal monsoon season rainfall recharge, $\mathrm{R}_{\mathrm{rf}}$ (normal) is then

$\mathrm{R}_{\mathrm{rf}}($ normal $)=\frac{\sum_{\mathrm{i}=1}^{\mathrm{N}}\left[\mathrm{R}_{\mathrm{rf}}(\text { normal })\right]_{i}}{\mathrm{~N}}$

\section{Recharge from rainfall infiltration factor method}

Recharge from rainfall in monsoon season by rainfall infiltration factor method based on rainfall infiltration factors which is given as

$\mathrm{R}_{\mathrm{rf}}=\mathrm{f} \times \mathrm{A} \times$ Normal rainfall in monsoon season (7)

Where,

$\mathrm{f}=$ Rainfall infiltration factor (For Indo Gangetic and Inland alluvial area, $\mathrm{f}=0.22$ )

$\mathrm{A}=$ Area of computation for recharge, ha

The same recharge factor may be used for both monsoon and non-monsoon rainfall, with the condition that the recharge due to nonmonsoon rainfall may be taken as zero, if the normal rainfall during the non-monsoon season is less than $10 \%$ of normal annual rainfall. In using the method based on the specified norms, recharge due to both monsoon and non-monsoon rainfall may be estimated for normal rainfall, based on recent 30 to 50 years of data. After the rainfall recharge for normal monsoon season rainfall using the water table fluctuation method has been estimated as described above, it is to be compared with the rainfall recharge estimated by rainfall infiltration factor method based on rainfall infiltration factors. For this a term percentage difference (PD) which is the difference between the two expressed as a percentage of the latter is computed as,

$\mathrm{PD}=\frac{\mathrm{R}_{\mathrm{rf}}(\text { normal, } \mathrm{wtfm})-\mathrm{R}_{\mathrm{rf}}(\text { normal }, \text { rifm })}{\mathrm{R}_{\mathrm{rf}}(\text { normal, rifm })} \times 100$

Where,

$\mathrm{R}_{\mathrm{rf}}$ (normal, wlfm) $=$ Rainfall recharge for normal monsoon season rainfall estimated by the water level fluctuation method 
$\mathrm{R}_{\mathrm{rf}}$ (normal, rifm) = Rainfall recharge for normal monsoon season rainfall estimated by the rainfall infiltration factor method

If $\mathrm{PD}$ is within $\pm 20 \%, \mathrm{R}_{\mathrm{rf}}$ (normal) $=\mathrm{R}_{\mathrm{rf}}$ (wlfm).

If $\mathrm{PD}$ is $<-20 \%, \mathrm{R}_{\mathrm{rf}}$ (normal) $=0.8 \times \mathrm{R}_{\mathrm{rf}}$ (rifm).

If $\mathrm{PD}$ is $>20 \%, \mathrm{R}_{\mathrm{rf}}$ (normal) $=1.2 \times \mathrm{R}_{\mathrm{rf}}($ rifm $)$.

The total recharge during the monsoon season for normal monsoon season rainfall condition is finally obtained as,

$\mathrm{R}($ normal $)=\mathrm{R}_{\mathrm{rf}}($ normal $)+\mathrm{R}_{\mathrm{gw}}+\mathrm{R}_{\mathrm{wc}}+\mathrm{R}_{\mathrm{t}}+$ $\mathrm{R}_{\mathrm{c}}(9)$

Where,

$\mathrm{R}($ normal $)=$ Total recharge during monsoon season, ha-m

$\mathrm{R}_{\mathrm{rf}}$ (normal) $=$ Rainfall recharge during monsoon season for normal monsoon season rainfall, ha-m

$\mathrm{R}_{\mathrm{gw}}=$ Recharge from ground water irrigation in the monsoon season for the year of assessment, ha-m

$\mathrm{R}_{\mathrm{wc}}=$ Recharge from water conservation structures in the monsoon season for the year of assessment, ha-m

$\mathrm{R}_{\mathrm{t}}=$ Recharge from tanks/ponds in the monsoon season for the year of assessment, ha-m

$\mathrm{R}_{\mathrm{c}}=$ Recharge from canal seepage in monsoon season for the year of assessment, ha-m

\section{Estimation of normal recharge during non monsoon season}

The recharge from rainfall during the nonmonsoon season may be estimated based on the rainfall infiltration factor method, provided the normal rainfall in the non-monsoon season is greater than $10 \%$ of the normal annual rainfall. If the rainfall is less than this threshold value, the recharge due to rainfall in the non-monsoon season may be taken as zero. Recharge during the non-monsoon season from other sources, namely from ground water irrigation $\left(\mathrm{R}_{\mathrm{gw}}\right)$, tanks $\left(\mathrm{R}_{\mathrm{t}}\right)$ and from water conservation structures $\left(\mathrm{R}_{\mathrm{wc}}\right)$ are to be estimated from the norms recommended in GEC-1997 or values obtained through field studies. The total recharge in the nonmonsoon season is obtained as the sum of recharge from rainfall in the non-monsoon season and recharge from other sources in the non-monsoon season.

\section{Total annual ground water recharge}

The total annual ground water recharge of the assessment unit is the sum-total of monsoon and non-monsoon recharge.

Annual recharge $=$ Recharge during monsoon + Recharge during non-monsoon.

\section{Net ground water availability}

It is the difference of annual ground water recharge and natural discharge during nonmonsoon season. An allowance is kept for natural discharge in the non-monsoon season by deducting $5 \%$ of total annual ground water recharge, if water table fluctuation method is employed to compute rainfall recharge during monsoon season and $10 \%$ of the annual ground water recharge if rainfall infiltration method is employed. The balance ground water available accounts for existing ground water withdrawal for various uses and potential future development withdrawal for various uses and potential future development. Net ground water availability is the difference of annual ground water recharge and natural discharge during non-monsoon season. 
Table.1 Profile of Aurangabad district

\begin{tabular}{|l|}
\hline Geographical area \\
\hline Population \\
\hline Literacy \\
\hline Subdivision \\
\hline No of blocks \\
\hline Headquarter \\
\hline Language \\
\hline Average rainfall \\
\hline Major crops \\
\hline Major rivers \\
\hline
\end{tabular}

\begin{tabular}{|l|}
\hline $3305 \mathrm{Km}^{2}$ \\
\hline $2,51,243$ \\
\hline 72.77 \\
\hline 2 \\
\hline 11 \\
\hline Aurangabad \\
\hline Bhojpuri \\
\hline 950.17mm \\
\hline Rice, Wheat, Gram, Vegetables etc. \\
\hline Sone, Punpun, Auranga \\
\hline
\end{tabular}

Table.2 Norms for ground water draft for Bihar state (GEC-97)

\begin{tabular}{|c|l|c|}
\hline \multirow{2}{*}{ State } & Type of ground water structure & Unit draft \\
\hline \multirow{3}{*}{ Bihar } & Dug wells & 0.6 \\
\cline { 2 - 3 } & Shallow tube wells & 1.0 \\
\cline { 2 - 3 } & Deep tube wells & 30.0 \\
\hline
\end{tabular}

Table.3 Average water table fluctuations in Aurangabad district

\begin{tabular}{|c|c|c|c|c|}
\hline S. No. & Year & Pre-monsoon & Post-monsoon & fluctuation \\
\hline 1. & 1998 & 5.32 & 4.09 & 1.23 \\
\hline 2. & 1999 & 5.32 & 4.10 & 1.22 \\
\hline 3. & 2000 & 5.22 & 4.46 & 0.76 \\
\hline 4. & 2001 & 5.78 & 4.52 & 1.26 \\
\hline 5. & 2002 & 5.83 & 4.50 & 1.33 \\
\hline 6. & 2003 & 5.62 & 4.57 & 1.05 \\
\hline 7. & 2004 & 5.70 & 5.28 & 0.42 \\
\hline 8. & 2005 & 5.15 & 5.13 & 0.02 \\
\hline 9. & 2006 & 6.41 & 5.76 & 0.65 \\
\hline 10. & 2007 & 6.40 & 4.99 & 1.41 \\
\hline 11. & 2008 & 6.39 & 4.50 & 1.89 \\
\hline 12. & 2009 & 6.36 & 4.83 & 1.53 \\
\hline 13 & 2010 & - & - & - \\
\hline & & 5.79 & 4.73 & 1.06 \\
\hline
\end{tabular}


Table.4 Ground water resource and development potential of Aurangabad district of Bihar

\begin{tabular}{|c|l|c|}
\hline S. No. & & \multicolumn{1}{|c}{ Component } \\
\hline
\end{tabular}

\section{Categorization of district}

The assessment units are categorized for ground water development based on status of ground water utilization and water level drain. The following four categories are - safe areas, which have ground water potential for development, semi critical areas, where cautious ground water development is recommended, critical areas and over exploited areas where there should be intensive monitoring and evaluation and future ground water development be linked with water conservation measures.

Ground water development (\%) = Existing ground water draft for all uses

Net annual ground water availability $\times 100(10)$

\section{Results and Discussion}

\section{Water table fluctuation}

The average water table fluctuation of Aurangabad district is displayed in table 3 .
The analysis of available data revealed that highest pre-monsoon water table depth $6.41 \mathrm{~m}$ was recorded in the year 2006 and lowest water table depth of $5.15 \mathrm{~m}$ was found in the year 2005. The average depth of water table in the pre-monsoon season is $5.79 \mathrm{~m}$.

The average rate of water decline is $0.10 \mathrm{~m}$ per year for the year (1998-2009). Postmonsoon water table fluctuation of Aurangabad district varies from $4.09 \mathrm{~m}$ in the year 1998 to $5.88 \mathrm{~m}$ in the year 2005 . The average depth of water table in the postmonsoon season is $4.80 \mathrm{~m}$. The average rate of water decline is $0.15 \mathrm{~m}$ per year for the year (1998-2009). The long term water table fluctuation in Aurangabad district varies from $0.02 \mathrm{~m}$ to $1.89 \mathrm{~m}$ with an average value of $1.06 \mathrm{~m}$. The available data reveals, water table fluctuation was lowest in the year 2005 and highest in the year 2008.

The lowest value of water table fluctuation in the year 2005 is due to very less amount of rainfall in 2005. Lower amount of rainfall has 
also speeded up the ground water pumpages for growing Kharif crop.

\section{Ground water resources}

The evaluation of groundwater potential is done using the water level fluctuation approach. Measurements of water levels are taken at a point source and the change in levels in the time span is observed. Annually replenishable dynamic ground water resources of the district have been estimated (GEC- 1997). The details of various components of ground water recharge in Aurangabad district is depicted in table 4. Data shows that total annual ground water recharge is 89882 ha-m for Aurangabad district. The existing ground water draft for irrigation is 15191 ha-m for Aurnagabad district. The ground water draft for all uses is 18703 ha-m for Aurangabad district. The net annual replenishable ground water resource is worked out to be 73054 ha-m for Aurangabad district. The net annual ground water available for future irrigation development is 56562 ha-m for Aurangabad district. The stage of ground water development is $23.1 \%$ for Aurangabad district. According to definitions used by CGWB Aurangabad district falls in safe category. The findings of the present study were in agreement with the other researchers (Kumar, C.P. 1989, Kaushal et al., 1997, Kumar, C.P. 2004, Mane et al., 2008, Ravi et al., 2008, Chatterjee et al., 2009).

The total groundwater recharge through rainfall, water harvesting structures and return flow of irrigation water in the study area was estimated as 89882 ha $\mathrm{m}$. The ground water draft for all uses is 18703 ha-m for Aurangabad district. The net annual replenishable ground water resource is worked out to be 73054 ha-m for Aurangabad district. The net annual ground water available for future irrigation development is
56562 ha-m for Aurangabad district. The stage of ground water development is $23.1 \%$ for Aurangabad district. According to definitions used by CGWB Aurangabad district falls in safe category. The study suggested that there is a good scope for future groundwater development and conjunctive use of canal irrigation and ground water needs to be promoted. Canal network and ground water potential needs to be tapped wisely for future development

\section{References}

Anonymous (1997) Report of the Ground Water Resource Estimation Committee, Central Ground Water Board, Ministry of Water Resources (Govt. of India), pp $1-154$

Chatterjee R, Gupta B. K., Mohiddin S. K. Singh P. N., Shekhar S., Purohit R. R. (2009) Dynamic groundwater resources of National Capital Territory, Delhi: assessment, development and management options. Environmental Earth Sciences, v 59(3):669-687

Government of India (2007) Report of the expert group on "Groundwater management and ownership" submitted to Planning Commission, September 2007. Government of India, Planning Commission, Yojana Bhavan, Parliamentary Street, New Delhi. 61 pages

Ground water resource estimation methodology (1997). Report of the Ground Water Resource Estimation Committee, Central Ground Water Board Ministry of Water Resources (Govt. of India). New Delhi, June 1997.

Kaushal, M.P., Singh, P. and Sondhu, S.K. (1997). Ground water potential of upper Bari Doab Canal tract of Panjab. J. Res. Punjab Agric. Univ. 34(3): 328-336.

Kumar C. P., 2004. Groundwater Assessment Methodology. Electronic Proceedings 
(CD); XXIII Annual convention of AHI and National seminar on water resources management and peoples participation, 10-11 December 2004, Baroda.

http://www.angelfire.com/nh/cpkumar/ publication/Lgwa.

Kumar, C.P. (1989). Assessment of ground water potential. Proceedings International Seminar on Development and Management of Ground Water Resources. University of Roorkee.

Mane, M.S., Singh, D.K., Bhattacharya, A.K. and Singh, A.K. (2008). Assessment of ground water potential for irrigation.
International-Journal-of-AgriculturalEngineering. 1(2): 74-80.

Ravi, E., Mayilswami, C., Raviraj, A., Thiyagarajan, G. and Ranghaswami, M. V., 2008. Groundwater Recharge Estimation in Noyil River Basin. In: Groundwater Resources Assessment, Recharge and Modelling. (Eds. Ranghaswami, M. V., Palanisami, K. and Mayilswami, C.). pp: 229-237. Macmillan India Ltd, New Delhi.

World Bank (1998) India water resources management sector review, New Delhi, rural Development Unit, south Asia Region pp1-192

\section{How to cite this article:}

Ravish Chandra, Shilpi Kumari, S.K. Jain and Singh, A.K. 2018. Assessment of Ground Water Resources for Irrigation in Aurngabad District of South Bihar, India. Int.J.Curr.Microbiol.App.Sci. 7(04): 1606-1617. doi: https://doi.org/10.20546/ijcmas.2018.704.181 